\title{
ENTREPRENEUR
}

Jurnal Bisnis Manajemen Dan Kewirausahaan

Program Studi Manajemen Fakultas Ekonomika dan Bisnis Universitas Majalengka

Published every January and July e-ISSN : (Proses), p-ISSN: 2723-1941

Available online https://ejournal.unma.ac.id/index.php/entrepreneur

\section{Pengaruh Self Efficacy dan Locus Of Control \\ Terhadap Kinerja Karyawan Dengan Kepribadian Sebagai Variabel Moderating (Studi Pada Pt. Wijaya Karya Beton, Tbk Ppb Majalengka)}

\author{
Deni Istiono \\ Fakultas Ekonomika dan Bisnis Universitas Majalengka \\ e-mail : deni.istiono@gmail.com.
}

\begin{abstract}
This study aims to determine the effect of self-efficacy and locus of control with personality as a modifying variable on the performance of employees of PT. Wijaya Karya Beton, Tbk PBB Majalengka. The data source in this research is primary data. The study population was all employees totaling 69 people. The sampling technique uses census techniques, where the entire population is used as a sample. The data collection instrument used a questionnaire. Data analysis techniques using Moderate Regression Analysis (MRA). The results of the analysis show that partially self-efficacy and locus of control have a positive and significant effect on employee performance. Likewise, the presence of personality as a moderating variable further strengthens the effect of self-efficacy and locus of control on employee performance. therefore the company must pay attention to individual beliefs, and expectations of their ability to achieve the goals of each job will depend on their level of confidence and self-confidence by increasing the capacity of employees through training activities and so on..

Keywords:

Self Efficacy; Locus Of Personality Control; and Performance
\end{abstract}




\section{ENTREPRENEUR}

Jurnal Bisnis Manajemen Dan Kewirausahaan

Program Studi Manajemen Fakultas Ekonomika dan Bisnis Universitas Majalengka

Published every January and July e-ISSN : (Proses), p-ISSN: 2723-1941

Available online https://ejournal.unma.ac.id/index.php/entrepreneur

\section{PENDAHULUAN}

Revolusi industri 4.0 saat ini menuntut perusahaan bersaing secara ketat. Perubahan lingkungan dan kemajuan teknologi informasi juga mendorong setiap perusahaan dapat memiliki keunggulan bersaing agar tidak tersingkirkan dalam persaingan yang dihadapi. Salah satu upaya perusahaan agar dapat bersaing, tumbuh dan berkembang adalah dengan menitikberatkan pada sumber daya manusia yang dimiliki agar setiap fungsi dapat bekerja dengan optimal. Perusahaan harus memiliki sumberdaya manusia dengan kemampuan teknis dan teoritis pada semua level.

Perusahaan yang memiliki sumber daya manusia handal merupakan landasan bersaing yang paling efektif. Hal ini karena persaingan bisnis yang didasarkan pada ide-ide baru, layanan pelanggan yang tinggi atau cepat, keputusan-keputusan yang akurat, sangatlah penting memiliki sumber daya manusia yang handal. Sumber daya manusia yang handal merupakan orangorang yang memberikan tenaga, bakat, kreativitas, dan kinerjanya tersebut kepada perusahaan agar suatu perusahaan dapat tetap mendapatkan eksistensinya. Setiap manusia memiliki kepribadian yang berbeda antara satu dengan yang lainnya. Oleh karena itu perusahaan harus pintar-pintar dalam memilih bakal calon karyawannya supaya keinginan perusahaan dapat tercapai dengan memiliki karyaan yang baik.

Horton (1982) dalam Ratno Purnomo dan Sri Lestari (146:2010), kepribadian adalah keseluruhan sikap, perasaan, ekspresi, dan temperamen seseorang. Sikap, perasaan, ekspresi, dan temperamen itu akan terwujud dalam tindakan seseorang jika dihadapkan pada situasi tertentu. Setiap orang mempunyai kecenderungan berperilaku yang baku, atau berpola dan konsisten, sehingga menjadi ciri khas pribadinya.

Kepribadian seorang karyawan bukanlah satu-satunya faktor yang berpengaruh terhadap jalannya suatu perusahaan. Selain kepribadian, self efficacy juga merupakan faktor yang penting dalam suatu organisasi. Bandura, (1986) dalam Alwisol, (287:2009) adalah tokoh yang memperkenalkan istilah efikasi diri (self-efficacy). Ia mendefenisikan bahwa self efficacy adalah keyakinan individu mengenai kemampuan dirinya dalam melakukan tugas atau tindakan yang diperlukan untuk mencapai hasil tertentu. self efficacy menekankan pada komponen keyakinan diri yang dimiliki seseorang dalam menghadapi situasi yang akan datang yang mengandung kekaburan, tidak dapat diramalkan, dan sering penuh dengan tekanan. Meskipun self efficacy memiliki suatu pengaruh sebab-akibat yang besar pada tindakan kita, self efficacy berkombinasi dengan lingkungan, perilaku sebelumnya, dan variabel-variabel personal lainnya, terutama harapan terhadap hasil untuk menghasilkan perilaku. Efikasi diri akan mempengaruhi beberapa aspek dari kognisi dan perilaku seseorang.

Seseorang dengan self efficacy tinggi percaya bahwa mereka mampu melakukan sesuatu untuk mengubah kejadian-kejadian di sekitarnya, sedangkan seseorang dengan self efficacy rendah menganggap dirinya pada dasarnya tidak mampu mengerjakan segala sesuatu yang ada disekitarnya. Dalam situasi yang sulit, orang dengan self efficacy yang rendah cenderung 


\section{ENTREPRENEUR}

Jurnal Bisnis Manajemen Dan Kewirausahaan

Program Studi Manajemen Fakultas Ekonomika dan Bisnis Universitas Majalengka

Published every January and July e-ISSN : (Proses), p-ISSN: 2723-1941

Available online https://ejournal.unma.ac.id/index.php/entrepreneur

mudah menyerah. Sementara orang dengan self efficacy yang tinggi akan berusaha lebih keras untuk mengatasi tantangan yang ada disekitarnya. Dalam kehidupan sehari-hari, self efficacy memimpin kita untuk menentukan citacita yang menantang dan tetap bertahan dalam menghadapi kesulitan-kesulitan. Lebih dari seratus penelitian memperlihatkan bahwa self efficacy meramalkan produktivitas pekerja. ketika masalah-masalah muncul, perasaan self efficacy yang kuat mendorong para pekerja untuk tetap tenang dan mencari solusi dari pada merenung ketidakmampuannya usaha dan kegigihan menghasilkan prestasi.

Selain kepribadian dan self efficacy karyawan yang dapat meningkatkan kinerja karyawan, Locus of control merupakan faktor penentu kinerja individu. Locus of control menjadi penting karena kotrol kinerja seseorang bisa diukur dari kemampuan seseorang dalam menguasai peristiwa yang terjadi pada dirinya. Locus of control merupakan salah satu variabel kepribadian yang didefinisikan sebagai keyakinan individu terhadap mampu tidaknya mengontrol nasib (destiny) sendiri Rotter (1966) dalam Meuthia Asri Amalia (35 : 2010). Individu yang memiliki keyakinan bahwa nasib atau peristiwa-peristiwa dalam kehidupannya berada di bawah kontrol dirinya dikatakan sebagai individu yang memiliki internal locus of control. Sementara itu, individu yang memiliki keyakinan bahwa lingkunganlah yang mempunyai kontrol terhadap nasib atau peristiwa-peristiwa yang terjadi dalam kehidupannya dikatakan sebagai individu yang memiliki external locus of control.

Kreitner dan Kinichi (2001) mengatakan bahwa hasil yang dicapai locus of control internal dianggap berasal dari aktivitas dirinya. Sedangkan pada individu dengan locus of control eksternal menganggap bahwa keberhasilan yang dicapai dikontrol oleh keadaan sekitarnya. Sementara Zimbardo (1985) menyatakan bahwa dimensi internal dan eksternal dalam locus of control dari Rotter memfokuskan pada strategi pencapaian tujuan tanpa memperhatikan asal tujuan tersebut. Bagi seseorang yang mempunyai internal locus of control akan memandang dunia sebagai sesuatu yang dapat diramalkan dan perilaku individu turut berperan di dalamnya. Sebaliknya, individu yang mempunyai external locus of control akan memandang dunia sebagai sesuatu yang tidak dapat diramalkan. Demikian juga dalam mencapai tujuan, perilaku individu tidak akan mempunyai peran di dalamnya.

Dalam mencapai suatu tujuan, setiap karyawan penting untuk meningkatkan kinerja mereka, untuk mencapai tujuan yang diharapkan oleh perusahaan. Menurut Mangkunegara (67:2005) mendefinisikan kinerja (prestasi kerja) sebagai berikut kinerja adalah hasil kerja secara kualitas dan kuantitas yang dicapai seorang pegawai dalam melaksanakan tugasnya sesuai dengan tanggung jawab yang diberikan kepadanya. Bernardin dan Russel dalam Mangkunegara, (68:2005), mengatakan bahwa kinerja adalah catatan hasil kerja/aktivitas tertentu yang dicapai selama periode tertentu". Kinerja tergantung pada kemampuan, usaha kerja dan kesempatan kerja yang dinilai dari output. Sementara Mathis dan Jackson (78: 2004) menyatakan bahwa kinerja pada dasarnya adalah apa yang dilakukan atau tidak dilakukan karyawan. Kinerja karyawan adalah yang memperngaruhi seberapa banyak mereka memberi 


\section{ENTREPRENEUR}

\section{Jurnal Bisnis Manajemen Dan Kewirausahaan}

Program Studi Manajemen Fakultas Ekonomika dan Bisnis Universitas Majalengka

Published every January and July e-ISSN : (Proses), p-ISSN: 2723-1941

Available online https://ejournal.unma.ac.id/index.php/entrepreneur

konstribusi kepada organisasi yang antara lain termasuk : kuantitas output, kualitas output, jangka waktu output, kehadiran di tempat kerja dan sikap kooperatif.

PT. Wijaya Karya Beton Tbk adalah salah satu perusahaan terbesar di Kabupaten majalengka, yang bertempat di Jalan Burujul Jatiwangi Kabupaten Majalengka. Wika Beton merupakan satu dari anak perusahaan yang berdiri pada 11 Maret 1997, anak perusahaan ini merupakan perluasan Wika Beton di bidang industri beton pracetak. Wika Beton telah memulai konsentrasi pada industri beton pracetak sejak tahun 1977 dengan mengembangkan produk beton pracetak untuk teras perumahan, dan lainlain. Sejak saat itu, Wika Beton bertekad mempertahankan pengembangan produk tersebut untuk mengantisipasi adanya pengembangan perencanaan dan datangnya proyek-proyek infrastuktur lain. Pengembangan produk tersebut telah menciptakan beberapa hasil seperti tiang beton untuk jalur pendistribusian energi dan bantalan beton pracetak serta produk lainnya seperti bantalan, bantalan rel kereta api, produk beton untuk jembatan, pipa, dinding penahan tanah dan bangunan gedung serta perumahan yang diimplementasikan untuk berbagai macam proyek. Produk-produk ini dihasilkan pada waktu yang tepat dan diprediksikan akan menjadi produk pemimpin di pasaran, ini akan tercapai jika mempunyai karyawan yang baik.

Dari pemaparan diatas, maka dapat disimpulkan bahwa self efficacy dan locus of control dapat mendorong karyawan untuk menghasilkan kerja yang optimal sesuai dengan target yang diharapkan oleh perusahaan. Demikian juga dengan kepribadian, kehadiran kepribadian juga akan menguatkan self efficacy dan locus of control terhadap kinerja karyawan.

\section{Tujuan Penelitian}

Penelitian ini bertujuan untuk mengetahui pengaruh self efficacy dan locus off control terhadap kinerja karyawan PT. Wijaya Karya Beton, Tbk PPB Majalengka. Serta pengaruh locus off control dan self efficacy yang dimediasi oleh kepribadian terhadap kinerja karyawan PT. Wijaya Karya Beton, Tbk PPB Majalengka.

\section{Mamfaat Penelitian}

Penelitian ini diharapkan dapat bermamfaat untuk menambah kajian Adapun manfaat penelitian lain, bagi Pengguna dapat menambah wawasan pengetahuan yang berhubungan dengan kinerja karyawan, bagi Perusahaan hasil penelitian ini dapat digunakan sebagai masukan dan bahan pertimbangan yang berarti., dan bagi Akademis sebagai bahan tambahan referensi, informasi dalam melakukan kegiatan penelitian selanjutnya guna melakukan analisa lebih baik, khususnya pada topik dan permasalahan ini.

\section{KERANGKA TEORITIS DAN HIPOTESIS Self Efficacy}

Self Efficacy adalah keyakinan mengenai kemampuan seseorang untuk menggerakan motivasi, sumber kesadaran, dan serangkaian tindakan yang dibutuhkan untuk menghadapi situasi yang menuntut (Gist. 1992:42). Sementara Bandura dan Bailey dalam Greenberg dan Baron, (2003:67) mengemukakan self efficacy adalah keyakinan seseorang terhadap kemampuan dirinya melakukan sesuatu 


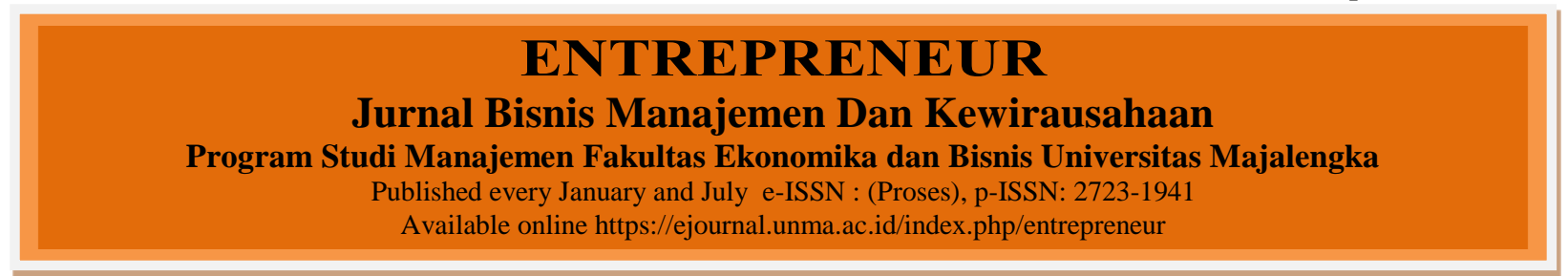

atau pekerjaan yang spesifik yang menjadi tanggung jawabnya.

Self efficacy bersifat situasional dan kontekstual, yaitu tergantung pada situasi yang dihadapi dan konteks tugas yang dihadapi. Adapun dimensi sekaligus indikator self efficacy menurut bandur (1986) dalam Noura Noormania (44:2014) yaitu :

1. Level, yaitu sejauh mana individu dapat menentukan tingkat kesulitan dalam pekerjaan yang mampu dilaksanakannya, penilaian dari aspek ini dapat dilihat dari beberapa hal, yaitu dengan melihat apakah individu dapat membuat target yang menantang, yakin dapat melakukan pekerjaan dengan baik, sekalipun pekerjaan tersebut dirasakan sulit, dan apakah individu tersebut mengetahui minatnya dan kemampuannya sehingga dapat memilih pekerjaan yang dirasakan sesuai.

2. Strength, yaitu sejauh mana kekuatan dan keyakinan akan level tersebut, apakah kuat atau lemah, yang dapat dilihat dari konsistensi individu tersebut dalam mengerjakan tugasnya. Aspek ini dapat dilihat melalui peningkatan usaha individu ketika menghadapi kegagalan, keyakinan individu dalam melakukan tugas dengan baik, ketenangan dalam menghadapi tugas yang sulit, dan komitmen dari individu tersebut dalam pencapaian target.

3. Generality, yaitu bagaimana seseorang mampu menggeneralisasikan tugastugas dan pengalaman-pengalaman sebelumnya ketika menghadapi suatu tugas atau pekerjaan, misalnya apakah ia dapat menjadikan pengalaman atau menjadi suatu hambatan atau bahkan diartikan sebagai kegagalan. Aspek ini dapat dinilai baik, jika individu dapat yakin bahwa pengalaman terdahulu dapat membantu pekerjaanya sekarang, mampu, menyikapi situasi yang berbeda dengan baik, dan menjadikan pengalaman sebagai jalan menuju sukses.

\section{Locus Of Control}

Locus of control menurut Spector sebagamanai dikutip oleh Munir dan Sajid, (134:2010) didefinisikan sebagai cerminan dari sebuah kecendrungan seorang individu untuk percaya bahwa dia mengendalikan peristiwa yang terjadi dalam hidupnya (internal) atau kendali atas peristiwa yang terjadi dalam hidupnya itu berasal dari hal lain, misalnya kuasa orang lain (eksternal). Sedangkan menurut Robbins (139:2007) locus of control adalah tingkat di mana individu yakin bahwa mereka adalah penentu nasib mereka sendiri. Faktor internal adalah individu yang yakin bahwa mereka merupakan pemegang kendali atas apaapa pun yang terjadi pada diri mereka, sedangkan faktor eksternal adalah individu yang yakin bahwa apapun yang terjadi pada diri mereka dikendalikan oleh kekuatan luar seperti keberuntungan dan kesempatan. Rotter dalam Friedman dan Schustrack, (326:2006) locus of control memiliki dua indicator sebagai berikut :

1. Locus of control internal, yaitu keyakinan bahwa keberhasilan yang diraih sebanding dengan usahayang mereka lakukan dan sebagian besar dapat mereka kendalikan. Individu yang kecenderungan Locus of Control internal memiliki keyakinan individu bahwa keyakinan yang dialami merupakan akibat dari perilaku dan tindakannya sendiri, memiliki kendali yang baik terhadap perilakunya sendiri, cenderung dapat mempengaruhi orang lain, yakin 


\section{ENTREPRENEUR}

\section{Jurnal Bisnis Manajemen Dan Kewirausahaan}

Program Studi Manajemen Fakultas Ekonomika dan Bisnis Universitas Majalengka

Published every January and July e-ISSN : (Proses), p-ISSN: 2723-1941

Available online https://ejournal.unma.ac.id/index.php/entrepreneur

bahwa usaha yang dilakukannya dapat berhasil, aktif mencari informasi dan pengetahuan terkait situasi yang sedang dihadapi.

2. Locus of control eksternal, yaitu keyakinan bahwa tindakan mereka memiliki sedikit dampak bagi keberhasilan atau kegagalan mereka, dan sedikit yang dapat mereka untuk merubahnya. Individu dengan Locus of Control eksternal memiliki keyakinan bahwa kekuasaan orang lain, dan takdir merupakan kesempatan merupakan factor utama yang mempengaruhi apa yang dialaminya, memiliki kendali yang kurang baik terhadap perilakunya sendiri, cenderung dipengaruhi oleh orang lain, sehingga tidak yakin bahwa usaha yang dilakukannya dapat berhasil, kurang aktif mencari informasi dan pengetahuan terkait situasi yang dihadapi.

\section{Kepribadian}

Kepribadian adalah beberapa ciri watak yang diperlihatkan seseorang secara lahir, konsisten, dan konsukuen". Setiap manusia melakukan proses sosialisasi, proses sosialisasi berlangsung selama manusia masih hidup didunia ini. Kepribadian seseorang individu dapat terbentuk dalam bertingkah laku, sehingga individu memiliki identitas khusus yang berbeda dengan orang lain (Koentjaraningrat, 203:1993). Sementara Jung dalam Alwisol (205:2007) mengemukakan "kepribadian mencakup seluruh fikiran, perasaan, dan tingkah laku, kesadaran dan ketidaksadaran. Kepribadian membimbing orang untuk menyesuaikan diri dari dengan lingkungan sosial dan lingkungan fisik".
Setiadi (15:2003), mengemukakan bahwa indikator kepribadian sebagai berikut :

1. Estraksi. Kepribadian yang mencirikan seseorang yang senang bergaul banyak bicara dan tegas.

2. Sifat menyenangkan. Kepribadian yang mencirikan seseorang yang baik hati dan mempercayai.

3. Sifat mendengarkan Pengawasan, yaitu tingkatan dimana pekerja dapat melaksanakan suatu fungsi pekerjaan tanpa memerlukan pengawasan seorang supervisor untuk mencegah tindakan yang tidak diinginkan.

\section{METODELOGI PENELITIAN}

Jenis penelitian ini adalah penelitian survey dengan pendekatan deskriptif dan verifikatif. Populasi penelitian adalah seluruh karyawan PT. Wijaya Karya Beton, Tbk PPB Majalengka yang seluruhnya berjumlah 69 orang. Pengambilan sampel dilakukan dengan tehnik sensus, yaitu seluruh populasi dijadikan sebagai sampel penelitian. Analisis data menggunakan tehnik Moderate Regression Analysis (MRA) yaitu uji statistik dengan menggunakan pendekatan analitik yang mempertahankan integritas sampel dan memberikan dasar untuk mengontrol variabel moderator. Tujuan dari analisis ini adalah untuk mengetahui apakah variabel moderasi akan memperkuat atau memperlemah hubungan antara variabel independen dan variabel dependen. Persamaan regresi dalam penelitian ini sebagai berikut :

$\mathrm{Y}=\alpha+\mathrm{b}_{1} \mathrm{X}_{1}+\mathrm{b}_{2} \mathrm{X}_{2}+\mathrm{b}_{3} \mathrm{X}_{3}+e$
$\mathrm{Y}=\alpha+\mathrm{b}_{1} \mathrm{Z}_{1}+\mathrm{b}_{2} \mathrm{Z}_{2}+e \ldots \ldots \ldots \ldots \ldots(1)$

Keterangan :

$\mathrm{Y}=$ Kinerja karyawan 


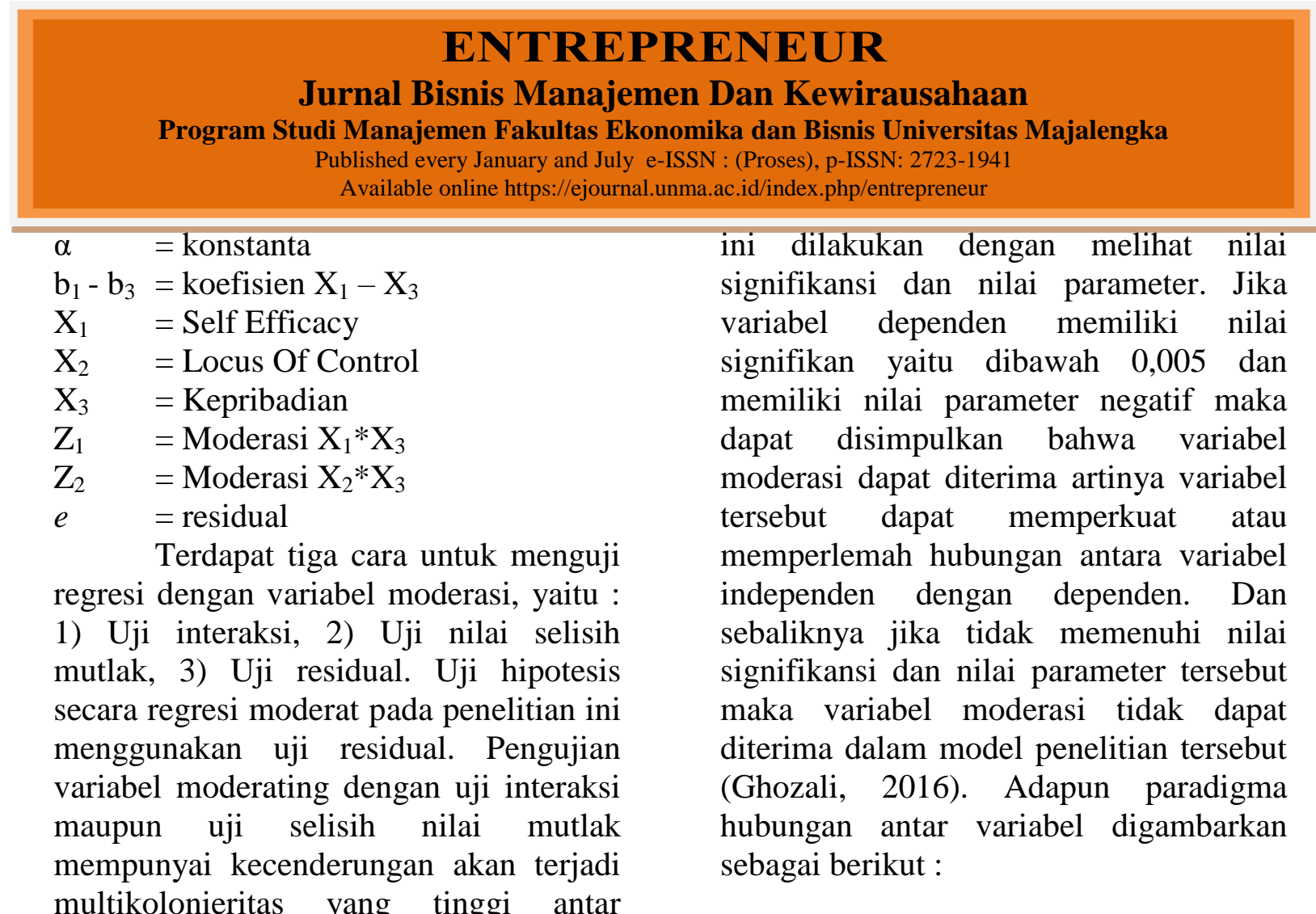

olonieritas yang tinggi antar variabel independen dan hal ini akan menyalahi asumsi klasik dalam regresi ordinary least square (OLS). Untuk mengatasi hal tersebut maka dikembangkan metode lain yang disebut uji residual ini (Ghozali, 2016). Analisis residual merupakan analisis yang menguji pengaruh deviasi (penyimpangan) dari suatu model. Fokus dari analisis ini adalah pada ketidak cocokkan (lack of fit) yang dihasilkan dari deviasi hubungan linier antar variabel independen. Dalam penelitian ini jika terjadi kecocokan antara variabel moderasi yaitu kepribadian dengan variabel independen self efficacy dan locus of control maka nilai residual kecil atau nol artinya setiap variabel independen dan moderasi memiliki nilai tinggi. Sebaliknya jika terjadi ketidak cocokan atau lack of fit antara variabel independen dan variabel moderasi maka nilai residual besar artinya nilai variabel independen tinggi, moderasi rendah dan dependen akan rendah.

Pengambilan keputusan moderate regression analysis dengan uji residual 


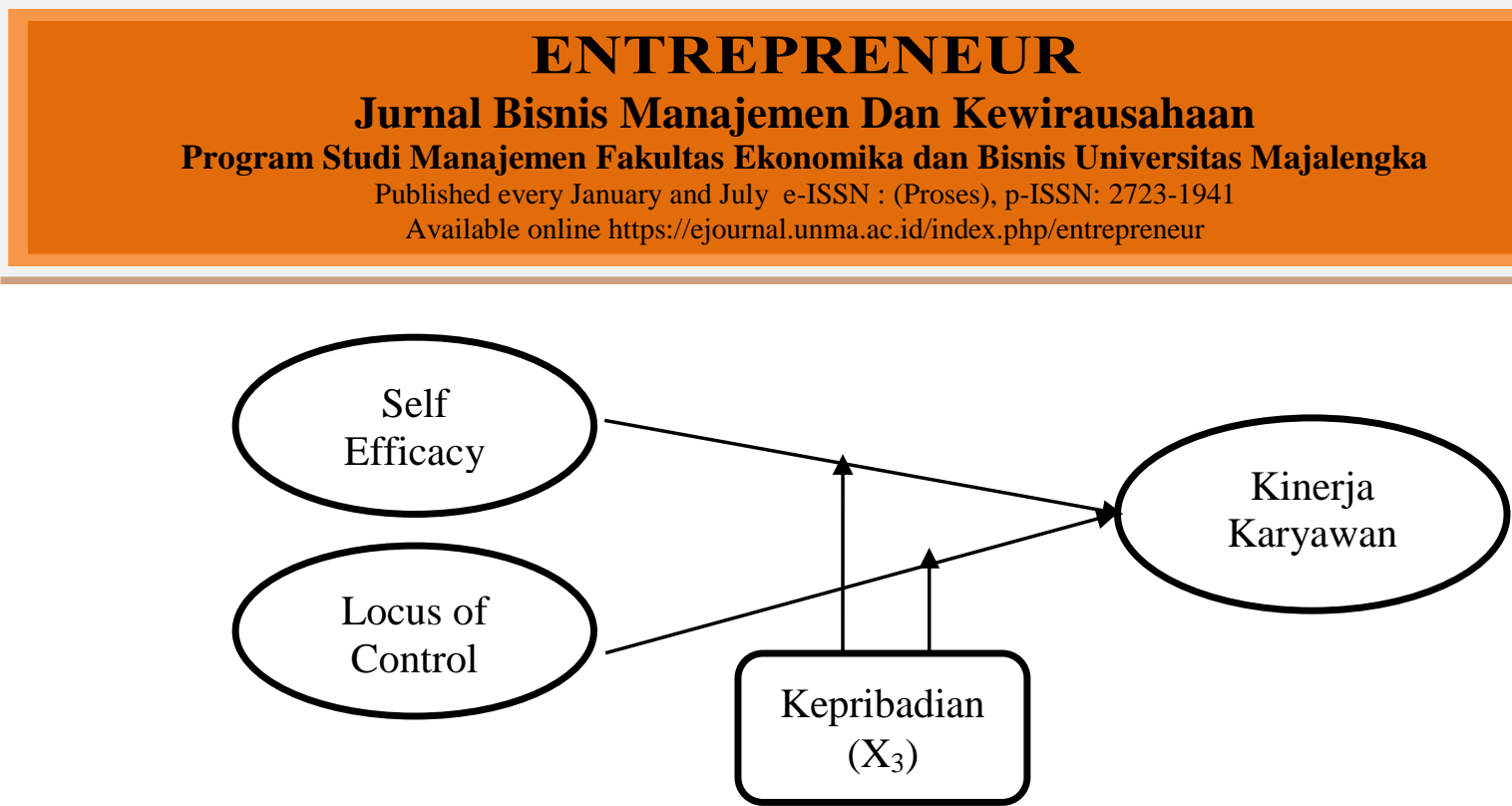

Gambar 1

Paradigma Hubungan Antar Variabel Penelitian

Metode penelitian ditulis dalam bentuk paragraf mengalir yang berisi desain penelitian yang digunakan (metode, jenis data, sumber data, teknik pengumpulan data,

\section{HASIL DAN PEMBAHASAN}

\section{Uji Instrumen Penelitian}

\section{Uji Reliabilitas dan Validitas}

Uji reliabilitas dilakukan untuk mengetahui instrumen yang digunakan untuk mengumpulkan data penelitian handal atau tidak handal. Reliabilitas pada dasarnya digunakan untuk mengetahui sejauh mana populasi, sampel, operasionalisasi variabel, teknik analisis data, pengukuran variabel) yang ditulis dalam bentuk paragraf mengalir (tidak dibuat numbering).

suatu hasil pengukuran relatif konsisten apabila pengukuran diulangi dua kali atau lebih. Dengan kata lain reliabilitas adalah indeks yang menunjukan sejauh mana suatu alat pengukur dapat dipercaya atau dapat diandalkan. Berikut ini hasil uji reliabilitas disajikan pada tabel 1 .

Tabel 1

Uji Reliabilitas

\begin{tabular}{|c|l|c|c|c|}
\hline No & \multicolumn{1}{|c|}{ Variabel } & Cronbach's Alpha & Nilai Kritis & Ket \\
\hline 1 & Kinerja Karyawan $(\mathrm{Y})$ & 0,780 & 0,6 & Reliabel \\
\hline 2 & Self Efficacy $\left(\mathrm{X}_{1}\right)$ & 0,797 & 0,6 & Reliabel \\
\hline 3 & Locus of Control $\left(\mathrm{X}_{2}\right)$ & 0,756 & 0,6 & Reliabel \\
\hline 4 & Kepribadian $\left(\mathrm{X}_{3}\right)$ & 0,744 & 0,6 & Reliabel \\
\hline
\end{tabular}

Sumber : data diolah (2019

Hasil uji cronbach's alpha sebagaimana disajikan pada tabel 1 diatas ini menunjukkan bahwa seluruh variabel penelitian memiliki nilai cronbach's alpha yang lebih besar dari nilai kritis 0,06. Dengan demikian dapat dinyatakan bahwa instrumen penelitian yang berupa kuisioner memiliki kehandalan untuk mengumpulkan data penelitian.

Selain uji reliabilitas, uji validitas juga dilakukan untuk 


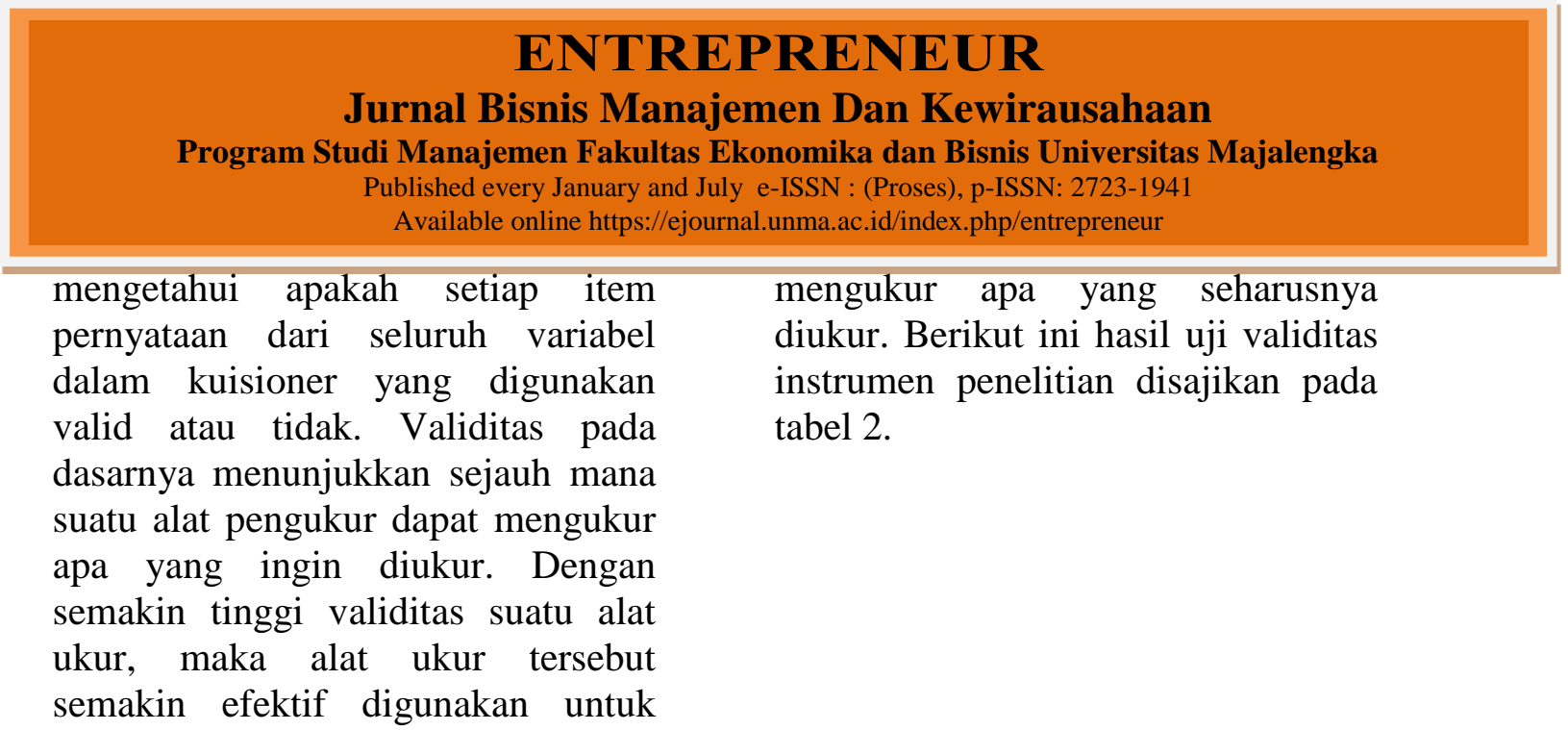

Tabel 2

Uji Reliabilitas

\begin{tabular}{|c|c|c|c|c|c|c|}
\hline \multirow[b]{2}{*}{ Pernyataan } & \multicolumn{4}{|c|}{ r-hitung } & \multirow{2}{*}{$\begin{array}{c}\text { r-tabel }(0,05) \\
=n-2 \\
=69-2 \\
=67\end{array}$} & \multirow[b]{2}{*}{ Ket } \\
\hline & $\begin{array}{c}\text { Kinerja } \\
\text { Karyawan } \\
\text { (Y) }\end{array}$ & $\begin{array}{c}\text { Self } \\
\text { Efficacy } \\
\left(\mathbf{X}_{1}\right)\end{array}$ & $\begin{array}{l}\text { Locus of } \\
\text { Control } \\
\left(\mathrm{X}_{2}\right)\end{array}$ & $\begin{array}{c}\text { Kepribadian } \\
\left(\mathbf{X}_{3}\right)\end{array}$ & & \\
\hline 1 & ,721 & ,600 & ,489 & ,382 & ,244 & Valid \\
\hline 2 & ,679 & ,614 & ,618 & ,386 & ,244 & Valid \\
\hline 3 & ,625 & ,883 &, 534 &, 757 &, 244 & Valid \\
\hline 4 & ,746 & ,781 & ,611 & ,769 & ,244 & Valid \\
\hline 5 & ,596 & ,898 & ,647 & ,757 & ,244 & Valid \\
\hline 6 & ,623 & ,681 &, 518 & ,756 &, 244 & Valid \\
\hline
\end{tabular}

Sumber : data diolah (2019)

Pada tabel 2 diatas diketahui seluruh variabel penelitian memiliki item pernyataan dengan nilai r-hitung lebih besar dari nilai r-tabel pada derajat kepercayaan 0,05 . Sehingga dapat dinyatakan bahwa seluruh variabel memiliki konstruk atau item pernyatan yang valid sebagai alat ukur pengumpulan data penelitian.

\section{Hasil dan Pembahasan \\ Pengaruh Self Efficacy $\left(\mathbf{X}_{1}\right)$ Terhadap Kinerja Karyawan (Y) \\ Pengaruh self efficacy $\left(\mathrm{X}_{1}\right)$ terhadap kinerja karyawan $(\mathrm{Y})$, tanpa variabel moderasi Kepribadian $\left(\mathrm{X}_{3}\right)$ disajikan pada tabel 3}

Tabel 3

Uji Regresi Berganda

\begin{tabular}{|c|c|c|c|c|c|c|}
\hline \multirow{3}{*}{\multicolumn{2}{|c|}{ Model }} & \multicolumn{3}{|c|}{ 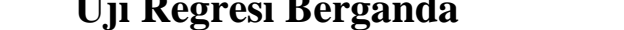 } & \multirow[b]{3}{*}{$\mathrm{t}$} & \multirow[b]{3}{*}{ Sig. } \\
\hline & & \multicolumn{2}{|c|}{$\begin{array}{l}\text { Unstandardized } \\
\text { Coefficients }\end{array}$} & \multirow{2}{*}{$\begin{array}{l}\text { Standardized } \\
\text { Coefficients } \\
\text { Beta }\end{array}$} & & \\
\hline & & B & Std. Error & & & \\
\hline 1 & (Constant) & 2,087 & 1,540 & & 1,356 &, 180 \\
\hline & $\mathrm{X} 1$ & ,679 & ,053 & ,784 & 12,836 & ,000 \\
\hline & $\mathrm{X} 2$ & ,262 & 079 & ,202 & 3,300 &, 002 \\
\hline
\end{tabular}

a. Dependent Variable: Y

Sumber : data diolah (2019) 


\section{ENTREPRENEUR}

\section{Jurnal Bisnis Manajemen Dan Kewirausahaan}

Program Studi Manajemen Fakultas Ekonomika dan Bisnis Universitas Majalengka Published every January and July e-ISSN : (Proses), p-ISSN: 2723-1941 Available online https://ejournal.unma.ac.id/index.php/entrepreneur

Pada tabel 3 tersebut diketahui bahwa self efficacy $\left(\mathrm{X}_{1}\right)$ memiliki nilai koefisien sebesar 0,679 dengan probabilitas 0,000 . Nilai probabilitas ini lebih kecil dari 0,05. Dengan demikian dapat dinyatakan bahwa self efficaccy $\left(\mathrm{X}_{1}\right)$ memiliki pengaruh positif dan signifikan terhadap kinerja karyawan (Y).

Hasil ini memberi makna bahwa meningkatnya self efficacy yang dimiliki seorang karyawan akan mendorong meningkatnya kinerja karyawan. Kilapong (2013) menyatakan self efficacy yang tinggi akan membuat karyawan lebih optimis dalam menyelesaikan pekerjaan yang di bebankan namun begitu juga sebaliknya apabila karyawan memiliki self efficacy yang rendah maka karyawan tersebut akan merasa kurang percaya diri dalam menyelesaikan pekerjaannya. Self efficacy dapat dikatakan sebagai faktor personal yang membedakan setiap individu, dimana perubahan self efficacy dapat menyebabkan perubahan perilaku terutama dalam penyelesaian tugas dan tujuan (Indrawati, 2014).

\section{Pengaruh Locus of Control $\left(\mathbf{X}_{1}\right)$ Terhadap Kinerja Karyawan (Y) \\ Pada tabel 3 diperoleh dapat} dilihat bahwa nilai koefisen locus of control $\left(\mathrm{X}_{2}\right)$ yang diperoleh sebesar 0,262 dengan probabilitas 0,002. Nilai probabilitas ini lebih kecil dari 0,05 . Dengan demikian dapat dinyatakan bahwa locus of control $\left(\mathrm{X}_{2}\right)$ memiliki pengaruh positif dan signifikan terhadap kinerja karyawan (Y).

Hasil ini memberi makna meningkatnya locus of control yang dimiliki seorang karyawan akan mendorong meningkatnya kinerja karyawan. Basak dan Ghosh, (2011) mengemukakan bahwa locus of control merupakan kepercayaan individu dalam mengontrol kejadian yang mempengaruhi dirinya. Semakin seorang karyawan suka bekerja keras, inisiatif, menemukan pemecahan masalah, dan berfikir seefektif mungkin, maka semakin tinggi kemauannya untuk berhasil dan tidak mudah menyerah, dia percaya bahwa kesuksesannya dikendalikan oleh dirinya sendiri tanpa bergantung pada orang lain.

Pengaruh Self Efficacy dan
Kepribadian $\left(\mathrm{Z}_{1}\right)$ Terhadap
Kinerja Karyawan $(Y)$
Pengaruh self efficacy dengan
variabel moderasi Kepribadian $\left(\mathrm{Z}_{1}\right)$
terhadap kinerja karyawan (Y)
disajikan pada tabel 4 dibawah ini :




\section{ENTREPRENEUR}

\section{Jurnal Bisnis Manajemen Dan Kewirausahaan}

Program Studi Manajemen Fakultas Ekonomika dan Bisnis Universitas Majalengka

Published every January and July e-ISSN : (Proses), p-ISSN: 2723-1941

Available online https://ejournal.unma.ac.id/index.php/entrepreneur

\section{Tabel 4}

\section{Uji Regresi Moderasi}

\begin{tabular}{|c|c|c|c|c|c|c|}
\hline \multirow{2}{*}{\multicolumn{2}{|c|}{ Model }} & \multicolumn{2}{|c|}{$\begin{array}{l}\text { Unstandardized } \\
\text { Coefficients }\end{array}$} & \multirow{2}{*}{$\begin{array}{c}\text { Standardized } \\
\text { Coefficients } \\
\text { Beta } \\
\end{array}$} & \multirow[b]{2}{*}{$\mathrm{t}$} & \multirow[b]{2}{*}{ Sig. } \\
\hline & & B & Std. Error & & & \\
\hline \multirow[t]{3}{*}{1} & (Constant) & 20,035 &, 420 & & 47,663 &, 000 \\
\hline & $\mathrm{Z} 1$ & ,208 & ,328 & ,036 & ,632 & ,010 \\
\hline & $\mathrm{Z} 2$ & ,939 & ,423 & ,133 & 2,218 & ,030 \\
\hline
\end{tabular}

a. Dependent Variable: Y

Pada tabel 4 tersebut diketahui bahwa self efficacy dengan variabel moderasi Kepribadian $\left(\mathrm{Z}_{1}\right)$ memiliki nilai koefisien sebesar 0,208 dengan probabilitas 0,010 . Nilai probabilitas ini lebih kecil dari 0,05. Dengan demikian dapat dinyatakan bahwa self efficaccy dengan variabel moderasi kepribadian $\left(\mathrm{Z}_{1}\right)$ memiliki pengaruh positif dan signifikan terhadap kinerja karyawan (Y).

Hasil ini memberi makna bahwa kehadiran variabel kepribadian dalam self efficacy akan meningkatkan secara nyata kinerja karyawan. Self efficacy merupakan bagian dari pengetahuan mengenai diri sendiri yang mampu memberikan pengaruh pada kehidupan sehari-hari manusia. Self efficacy dapat juga dikatakan sebagai faktor personal yang membedakan setiap individu. Perubahan self efficacy dapat menyebabkan terjadinya perubahan perilaku terutama dalam penyelesaian tugas dan tujuan. Kehadiran kepribadian dalam self efficacy akan membimbing setiap karyawan untuk menyesuaikan diri dengan lingkungan kerja, sosial dan fisik yang dihadapi. Semakin baik seorang karyawan dalam berinteraksi mengendalikan dirinya maka semakin baik pula kinerjanya.

Pengaruh Locus of Control dan Kepribadian $\left(\mathbf{Z}_{2}\right) \quad$ Terhadap Kinerja Karyawan (Y)

Pada tabel 4 diatas diketahui bahwa nilai koeofisien locus of control dengan variabel moderasi Kepribadian $\left(\mathrm{Z}_{2}\right)$ sebesar 0,939 dengan probabilitas 0,030 . Nilai probabilitas ini lebih kecil dari 0,05. Dengan demikian dapat dinyatakan bahwa locus of control dengan variabel moderasi kepribadian $\left(Z_{2}\right)$ memiliki pengaruh positif dan signifikan terhadap kinerja karyawan (Y).

Hasil ini memberi makna bahwa kehadiran variabel kepribadian dalam locus of control akan meningkatkan secara nyata kinerja karyawan. Dengan kata lain jika karyawan memiliki tanggung jawab yang tinggi, dapat diandalkan, tekun dan berorentasi prestasi serta menyenangkan bagi rekan kerjanya. Maka semakin tinggi kemampuannya mengendalikan diri untuk menyelesaikan pekerjaan yang dibebankan pada dirinya. 


\section{ENTREPRENEUR}

Jurnal Bisnis Manajemen Dan Kewirausahaan

Program Studi Manajemen Fakultas Ekonomika dan Bisnis Universitas Majalengka Published every January and July e-ISSN : (Proses), p-ISSN: 2723-1941 Available online https://ejournal.unma.ac.id/index.php/entrepreneur

\section{SIMPULAN DAN IMPLIKASI KESIMPULAN}

Berdasarkan hasil analisis yang telah dilakukan, dapat disimpulkan sebagai berikut, Self efficacy memiliki pengaruh positif dan signifikan terhadap kinerja karyawan; locus of control memiliki pengaruh positif dan signifikan terhadap kinerja karyawan, Self efficacy dengan kepribadian sebagai variabel moderasi memiliki pengaruh positif dan signifikan terhadap kinerja karyawan dan locus of control dengan kepribadian sebagai variabel moderasi memiliki pengaruh positif dan signifikan terhadap kinerja karyawan.

\section{DAFTAR PUSTAKA}

Alwisol. 2009. Psikologi Kepribadian edisi Revisi. Malang: Universitas Muhammadiyah Malang Press

Anwar Prabu Mangkunegara , 2005 "Manajemen sumber daya manusia" . Perusahaan PT Remaja Rosda Karya; Bandung.

Chamariyah, 2015 "Pengaruh self efficacy, Assertiveness, dan self esteem terhadap keinginan pindah kerja (turnover intentions) pegawai (Studi bank jatim cabang pamekasan) Jurnal Ne0-Bis Vol.3, No.1

Edwin B. Flippo, 2012. "Personel Management (Manajemen Personalia), Edisi VII Jilid

\section{IMPLIKASI}

Untuk meningkatkan kinerja karyawan PT. Wijaya Karya Tbk. PBB Majalengka, hendaknya perusahaan memperhatikan keyakinan, dan harapan individu terhadap kemampuannya. Selain itu perusahaan juga harus mampu membangun emosional karyawan agar memiliki keyakinan bahwa pencapaian tujuan setiap pekerjaan akan sangat tergantung pada tingkat keyakinan dan kepercayaan diri mereka sendiri. Cara ini dapat dilakukan dengan meningkatkan kapasitas karyawan melalui kegiatan seperti pelatihan, familiy gatering dan sebagainya.

\section{II, Terjemahan Alponso $S$ " Jakarta; Erlangga}

Friedman, Howards S., \& Miriam Schustack. (2006). Kepribadian: Teori Klasik dan Riset Modern. Jakarta: Erlangga

Husein Umar, 2003, Metodologi Penelitian Untuk Bisnis, Jakarta; PT. Gramedia Pustaka.

Imam. Ghozali 2006. Aplikasi Analisis Multivariate Dengan Program SPSS. CetakanKeempat. Semarang: Badan Penerbit Universitas Diponegoro.

Kerlinger. 1973. Metode penelitian. Jakarta: Erlangga

Koentjaraningrat. 1993. "Metode-metode Penelitian Masyarakat". Jakarta; PT. Gramedia Pustaka Utama.

Malayu, S.P. Hasibuan, 2007. "Manajemen Sumber Daya 


\section{ENTREPRENEUR}

Jurnal Bisnis Manajemen Dan Kewirausahaan

Program Studi Manajemen Fakultas Ekonomika dan Bisnis Universitas Majalengka Published every January and July e-ISSN : (Proses), p-ISSN: 2723-1941 Available online https://ejournal.unma.ac.id/index.php/entrepreneur

Manusia”. Jakarta : Cetakan 9. PT. Bumi Aksara.

Mathis, dan Jackson, 2006, Manajemen Sumber Daya Manusia, Edisi pertama,

Cetakan Pertama, Yogyakarta : Salemba Empat

Moh Nazir. (2003),Metode Penelitian, Salemba Empat, Jakarta,63Arikunto, S (2002). Prosedur Penelitian, Suatu Pendekatan Praktek. Jakarta: PT Rineka Cipta
Ruky , 2004 "Sistem manajemen kinerja", Ggramedia pustaka utam. Jakarta

Robbins SP, dan Judge. 2007. Perilaku Organisasi, Jakarta: Salemba Empat Setiadi, 2003 "Teori kepribadian", Bumi aksara; Jakarta

Simanjuntak, Payaman J. 2005. Manajemen dan Evaluasi Kerja. Lembaga Penerbit FEUI, Jakarta.

Sugiono, 2013 "Statistika untuk penelitian”, Alfabeta; Bandung 